\title{
Print Journalism in Morocco: From the Pre-colonial Period to the Present Day
}

\author{
Hamza Tayebi \\ Master Student in Cultural Studies \\ Sidi Mohamed Ben Abdellah University Dhar Mehraz, Fez-Morocco \\ Email: tayebi_hamza@hotmail.fr
}

Doi:10.5901/mjss.2013.v4n6p497

\begin{abstract}
Print journalism today represents one of the most influential media of communication in Morocco. This article derives its relevance from the fact that the history of print journalism in Morocco has not been covered thoroughly, especially in English. On the contrary, much ink has been shed on the press in the contemporary Morocco, without focusing sufficiently on the precolonial as well as the colonial circumstances that led to the establishment of a solid journalism infrastructure in the country. This article is but an attempt to bring to the fore the history of the Moroccan press and to discuss it within the pre-colonial, colonial, and post-colonial contexts. It is divided into two sections. The first one deals with the press before and during colonialism, while the last one mainly discusses the Moroccan press in its contemporary context, relating it to multiple issues such as censorship, self-censorship, and democratization.
\end{abstract}

Keywords: Print Journalism; Moroccan Press; Newspaper; Colonial Period; Censorship; Red Lines

\section{Moroccan Press before and during the Colonial Period}

Before the colonial experience in Morocco (1912-1956), many newspapers appeared in various languages. Still, there was not a well-established culture of journalism in Morocco due to the fact that the material and technical infrastructure was very weak in the country in comparison with Europe. What is important, if not natural, is that a lot of efforts were made hopefully to make the people aware of the latest news. There was a use of traditional means in order to circulate news among the public, and such means were, and some of them are still, deeply rooted in the Moroccan culture. In his La Presse Marocaine D'Expression Française: Des Origines A 1956, Jamaà Baida (1996) points out some of these means. He starts with Les barrah s (public criers) who were people working with the Makhzenean ${ }^{1}$ or with the tribal authorities, and who were entrusted with walking in the neighborhoods or in souks and saying loudly the latest news. (Baida, 1996, p. 31) The religious sermon that still takes place in mosques and zawias ${ }^{2}$ was another means used, especially on special occasions, so as to either comment on social, economic, or political events or send a particular message (Ibid., p. 31). Here, the religious sermon becomes a mediator between the state and the community. However, thanks to Morocco's geographic proximity to Europe, especially to Spain, and also thanks to the heterogeneity of its population, newspapers appeared quite early.

Tangiers, the Northern Moroccan city that is very close to Europe and that lies at the entrance of Gibraltar, played a significant role in the history of the press in Morocco. This proximity, along with having made Morocco a center of attraction for different European newspapers, enabled some European ideas such as the freedom of expression to be easily imported to the country. Along with that, the proximity to Europe helped most importantly in the introduction of the first printing press in Tangier in the 1880's by a Gibraltarian, under the name of Gregory T. Abrines. (El Ayadi, 2007, p. 5) The Spanish newspaper El Eco de Tétuàn is said to be the first newspaper to be published in Morocco, and the first issue was published in May 1't 1860 (Baida, 1996, p. 33). El Eco de Tétuàn was edited in Tetouan and its editor, Pedro

${ }^{1}$ The Makhzen was consolidated at the 17th century, and was initially used to collect taxes and to wage wars before becoming a synonym of the Moroccan bureaucratic and security apparatus.

${ }^{2}$ A zaouia or zawiya, as defined in Wikipedia, the Free Encyclopedia, is an Islamic religious school or monastery. The term is Maghrebi and West African, roughly corresponding to the Eastern term madrassa. A zawiya often contains a pool, and sometimes a fountain. 
Antonio de Alarcon, was Spanish, and he was very proud of having brought the invention of Gutenberg to an African country (Ibid., p. 38).

Other references claim that Al-Mughrib Al-aksa, a Spanish weekly, was the first newspaper to see light in Morocco, and that it was Gregory T. Abrines himself who first directed the newspaper in January 1883 (El Ayadi, 2007, p.5). All these newspapers were "the mouthpiece of their respective Legations." (Ibid., p. 6) The case of the Times of Morocco, an English newspaper that first appeared in July 1884 and that was edited by Edward E. Meakin, was different in the sense that it "adopted a line contrary to that of British policy in Morocco." (Ibid.) In the beginning, the Times of Morocco had been monthly, but from 1886 its editor was able to turn it to a weekly newspaper, especially because he, as noted in Meakin's insightful book The Moorish Empire, managed to import his press so as "to express himself with sufficient freedom". (Meakin, 1899, p. 534) Its editors were very critical of British official policy followed by Sir John Drummond Hay, the British minister in Tangier. (El Ayadi, 2007, p. 7) Because of financial problems, this newspaper was "taken over by Al- Mughrib Al-aksa in 1893, which from then on was published in English." (Ibid., p. 6) It is worth noting that the Sultan Sidi Mohammed Ben Abderrahmane ${ }^{3}$, who was known by his openness to the occidental inventions, did paradoxically put the printing machine under the power of the Makhzen so as to censor the publications. (Baida, 1996, p. 34)

Many other newspapers in other languages appeared after El Eco de Tétuàn and the other aforementioned newspapers. In July of 1883, Le Reveil du Maroc, a French weekly newspaper, appeared in Morocco, and it was under the ownership and the direction of Levi A. Cohen, a Jew born in Morocco, and who had a British nationality. (Cohen, 2007, p. 42) It appeared in Tangier and it was presented as the first newspaper edited in French, ignoring Jean Louis Miege's La Gazette de Tanger which was first published in 1870. (Ibid., p. 44) Cohen's Le Réveil du Maroc showed interest in politics and commerce, and it clearly supported Moroccan Israelite's interests. (Ibid., p. 65) This newspaper, edited in French, appeared three years after the international conference of Madrid (1880) when Europe started showing interest in Morocco. (Ibid., p. 64) Le Réveil du Maroc was circulated in Tangier, mostly in the European colony as well as among the Israeli bourgeoisie (Ibid., p. 66), and it contributed a great deal not only to the spread of the French language but also to the French ideals in Morocco. (Ibid., p. 72) The editor of this newspaper encountered serious financial difficulties, and this, accordingly, badly weakened its circulation.

Figure 1: Le Réveil du Maroc

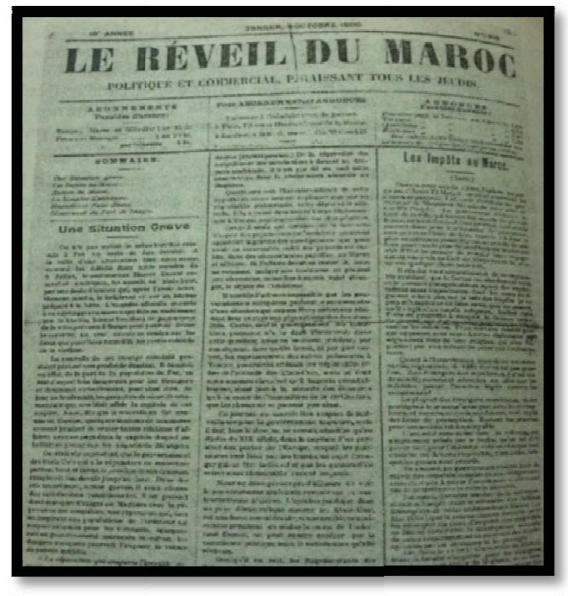

The Makhzen did not put obstacles in the way of foreign newspapers in Morocco. Instead, it did highly welcome them, allowing even some good articles to be translated into Arabic and circulated among Moroccans, especially in Tangier, as long as these newspapers did not tackle the religious and political taboos. (Baida, 1996, pp. 52-3)

The diversity that characterized the Moroccan society played a significant role in the emergence of various newspapers that used to represent different communities in different languages. In his insightful La Presse Juive Editée

3The Moroccan Sultan who reigned between 1859 and 1873. 
au Maroc: 1870-1963, Pierre Cohen interestingly gives us a picture of the Jewish press in Morocco from 1870 till 1963. Through his archival footages of Jewish newspapers, either in French or in Hebrew, Cohen shows the richness of the history of the press in Morocco. Mebasser Tob and Moghrabi are for example two Jewish newspapers published in Morocco, exactly in Tangier. Mebasser Tob, a weekly newspaper, first appeared in 1893, and it was founded by Salomom Benaioun. (Cohen, 2007, p. 81) This Jewish newspaper was published in Arabic Hebrew (Hudéo Arabe) and it focused primarily on information regarding the Jews and the Jewish communities worldwide. (Ibid.) Salomom Benainoun was himself the same editor of Le Moghrabi which was a weekly Jewish newspaper founded in 1903 and suddenly disappeared in 1904 (Ibid., p. 84) without any clear and known reason. (Ibid., p. 85) It was published in French and also in Arabic Hebrew. (Ibid., p. 84) Le Moghrabi marked the end of the Jewish press of the pre-colonial period. (Ibid., p. 63) For the sake of brevity, the chart below gives an idea about the most well-known newspapers that were edited in French between 1870 and 1911. (Ibid., p. 44)

Table 1: Newspapers edited in French between 1870 and 1911

\begin{tabular}{|l|c|c|c|}
\hline Title & Periodicity & Language & Date of Appearence \\
\hline La Gazette de Tanger & Weekly & French & 1870 \\
\hline Le Réveil du Maroc & Weekly & French & 1883 \\
\hline Al Moghreb Al-Aksa & Weekly & Spanish & 1883 \\
\hline The Times of Morocco & Weekly & English & 1884 \\
\hline El Eco Mauritano & Weekly & Spanish & 1886 \\
\hline Le Commerce au Maroc & Weekly & French & 1886 \\
\hline El Diario de Tanger & Weekly & Spanish & 1889 \\
\hline Kol Israel & Weekly & Hebrew & 1891 \\
\hline Mebasser Tob & Weekly & Hebrew & 1893 \\
\hline La Cronica & Weekly & Spanish & 1893 \\
\hline Le Maroc Commerical & Monthly & French & 1895 \\
\hline El Porvenir & Daily & Spanish & 1900 \\
\hline Le Maroc & Weekly & French & 1903 \\
\hline Le Journal du Maroc & Weekly & French & 1903 \\
\hline Le Moghrabi & Weekly & French and Hebrew & 1903 \\
\hline Es-Saada & Weekly & Arabic & 1904 \\
\hline La Dépêche Marocaine & Daily & French & 1905 \\
\hline Es- Sabah & Weekly & Arabic & 1906 \\
\hline Lissan Al Maghrib & Weekly & Arabic & 1907 \\
\hline Le Courrier du Maroc & Weekly & French & 1907 \\
\hline L'Indépendence Marocaine & Weekly & French & 1907 \\
\hline Al Fajr & Weekly & Arabic & 1908 \\
\hline Le Petit Marocain & Weekly & French & 1911 \\
\hline
\end{tabular}

It would go without saying that the linguistic and cultural diversity of Morocco along with its geographical proximity to Europe, especially to Spain and France, contributed tremendously to the rise and circulation of newspapers in Morocco as well as to the their linguistic richness, as the chart above clearly shows. It is worth noting that the Moroccan Israelis, particularly the ones of Tangiers, were the pioneers in the domain of the press in Morocco. (Baida: 1996, p. 86) As Jamaà Baida notes, the Jewish press in French brought valuable contribution towards the attainment of the French colonial project in the country, seeing that the Jewish elite was gradually inclined to French. (Ibid., pp. 86-7) In general, the development of the Moroccan press started with the protectorate system, especially with Lyautey ${ }^{4}$, the first Resident General in Morocco. (Ibid., p. 87)

The decree of April 27 ${ }^{\text {th }}, 1914$ appeared as the first law aiming at the codification of the press in Morocco. (Ibid., p. 94) This decree gave privilege to the French press during the "protectorate". (Ibid.) The protectorate regime in Morocco (March 1912) aimed at establishing the necessary infrastructure of journalism as a form of "modernizing" the country. It would be interesting to note here that Jean-Claude Allain argues that the press in general is among the manifestations of modernity. (Ibid., p. 11) January 1914 marked a very starting point of the establishment of a press culture in Morocco 
owing to the fact that the country witnessed the appearance of Havas, a famous Parisian printing house at that time. (Ibid., p. 96) Accordingly, many new newspapers saw light and many other existing ones joined Havas such as La Presse Marocaine, Le Progrès Marocain, and L'Echo du Maroc. Nevertheless, the protectorate regime, as I see it, did not make efforts to help increase the number of newspapers in Morocco or to contribute to the modernization of the country. Rather, it aimed primarily at instilling the French language and culture in Morocco in order to easily exert a form of cultural hegemony, to put it in Gramscian terms.

The French authorities, as Baida notes (Ibid.), tightly controlled Havas, and this immeasurably helped them determine what could be published; that is, the French authorities could easily interfere in Havas in order to select the "suitable" articles and information for publication. Still, there were many newspapers edited in French that were against the protectorate regime. L'Echo du Maroc is one of these newspapers, and in 1919 it published articles that toughly criticized the protectorate regime in general and Lyauté's administration in particular. (lbid., pp. 99-101) "Ou allonsnous?", published on February 9th 1919 , and "La politique d'association: Leur point de vue", published on February $11^{\text {th }}$, 1919, are good examples of these articles. On the whole, the number of newspapers unprecedentedly increased, especially in 1923 and chiefly in Casablanca, the economic capital of Morocco. Some of the editors at that time could not continue publishing for two main reasons: in the first place for financial reasons and secondly for the dearth of papers at that time. (Ibid., pp. 96-8)

Interestingly, the number of newspapers, especially the ones edited in French, will substantially increase with the departure of Lyautey in 1925 and the appointment of Théodore Steeg as a new General Resident in Rabat. Theodore Steeg, unlike the military Lyautey, was a civil protestant and a member of the radical socialist party. (Ibid., p. 143) His personality in fact was reflected in his actions, and little by little many press agencies were set up in Morocco and many new newspapers appeared. Some of these newspapers were interested in information while some others stridently repeatedly criticize the policies of the protectorate regime. What characterized the period of Steeg is the proliferation of weekly newspapers, and exactly seventeen new weeklies appeared during his reign. (Ibid., p. 158) On top of that, Steeg's period was also marked by the politicization of the press in Morocco. Indeed, each new newspaper, especially the ones edited in French, had its own specific political color. For instance, L'Etre Française and Redd-Balek were socialist while Le Potins $d u$ Maroc and Casa qui Rit were very humorous. The chart below gives an idea about the newspapers edited in French that appeared under the reign of Théodore Steeg. (Ibid., p. 163)

Table 2: Newspapers edited in French under the reign of Théodore Steeg

\begin{tabular}{|l|c|c|}
\hline Title & Place of Appearance & Date of Appearance \\
\hline L'Echo du Bled & Casablanca & March 1926 \\
\hline L'Etre Française & Casablanca & May 1926 \\
\hline Le Travail & Oujda & Juin 1926 \\
\hline La Bougie de Fez & Fez & September 1926 \\
\hline L'Echo de France & Casablanca & October 1926 \\
\hline Les Annales Marocaines & Casablanca & 1926 \\
\hline Le Cri de Maàrif & Casablanca & 1926 \\
\hline La Voix du Sud & Marrakech & 1926 \\
\hline Le Réveil du Moghreb & Marrakech & 1926 \\
\hline La Vie Casablancaise & Casablanca & January 1927 \\
\hline Les Potins du Maroc & Rabat & March 1927 \\
\hline Redd-Balek & Casablanca & July 1927 \\
\hline L'Antenne Marocaine & Casablanca & November 1927 \\
\hline La Vérité Marocaine & Rabat & 1927 \\
\hline L'Avenir de Fez & Fez & January 1928 \\
\hline Casa qui Rit & Casablanca & September 1928 \\
\hline Radio Phare & Casablanca & October 1928 \\
\hline
\end{tabular}

As mentioned before, this increase in newspapers edited in French aimed at marginalizing the Arabic language as well at instilling a French culture and identity in Morocco. Some promising Moroccan newspapers edited in Arabic were harassed by the colonial authorities, and "Idhar Lhaq" is a case in point. (www.habous.net) Besides, the colonial authorities did not allow also other Syrian, Egyptian, Tunisian, and Algerian newspapers edited in Arabic to have access to Morocco in order that there would be no influence on the Moroccans by the revolutionary and nationalistic attitudes of 
these newspapers. Unfortunately, the number of newspapers edited in Arabic was comparatively limited, while some particular areas like the southern region, without including Ifni region, seriously lacked newspapers. (Ibid.) This was noticed especially in the beginning of colonialism in Morocco in the sense that the country was obliged to have for ten years only one Arabic newspaper, which is "Assaada", and which was the official voice of the protectorate regime! (Ibid.)

It is interesting to point out that newspapers edited in Arabic during the colonial period mushroomed thanks to the efforts of the nationalists who normally looked for effective platforms whereby to transmit their nationalistic ideas, to express their complete and steadfast refusal of colonialism in Morocco, and to express also their attachment to the Sultan. (Ibid.) Very often were such newspapers shut down by the French colonial authorities, and because of this policy some Moroccan nationalists, especially students from Fez, started publishing in secret newspapers like "Al Islah" newspaper, and this immensely affected significant portion of Moroccans. (Ibid.) Since 1930, nationalistic newspapers edited in Arabic knew an unprecedented circulation, and they severely criticized the violations of the protectorate regime in Morocco, trying also to set up new foundations of the Moroccan press in Morocco. Interestingly, some nationalists, who received a French education like Abdellatif Sbihi ${ }^{5}$ and many others, found it important to give rise to a nationalistic press edited in French and published outside, mainly in France. (Baida, 1996, p. 197) Mohammed Hassan El-Ouazzani, who resided in Paris and Geneva, contributed also in this particular type of newspapers, and he specifically was among the principal Moroccan collaborators of Maghreb and of L'Action du Peuple. (Ibid., pp. 199-211) This was very important in the sense that such newspapers and such journalists managed to criticize colonialism through the language of the colonizer. Needless to mention that thanks to their residence in France, they were able also to criticize France from within.

The year of 1952 marked the birth of the national press, especially with the return of the Moroccan Sultan, Mohammed Ben Youssef, from exile, and also especially after the emergence of political parties like the /stiqlal party (the Independence Party). (Ibid., p. 389) The Sultan Mohammed V, after his return from exile, showed interest in the press in general and started meeting with Moroccan, French, and Jewish newspaper editors. The Sultan's meeting with Jaques Dahan, the editor of Voix des Communautés, in December 1955 is an example.

Figure 2: Mohammed V's meeting with J. Dahan, the editor of Voix des Communautés (Cohen, 2007, p. 258)

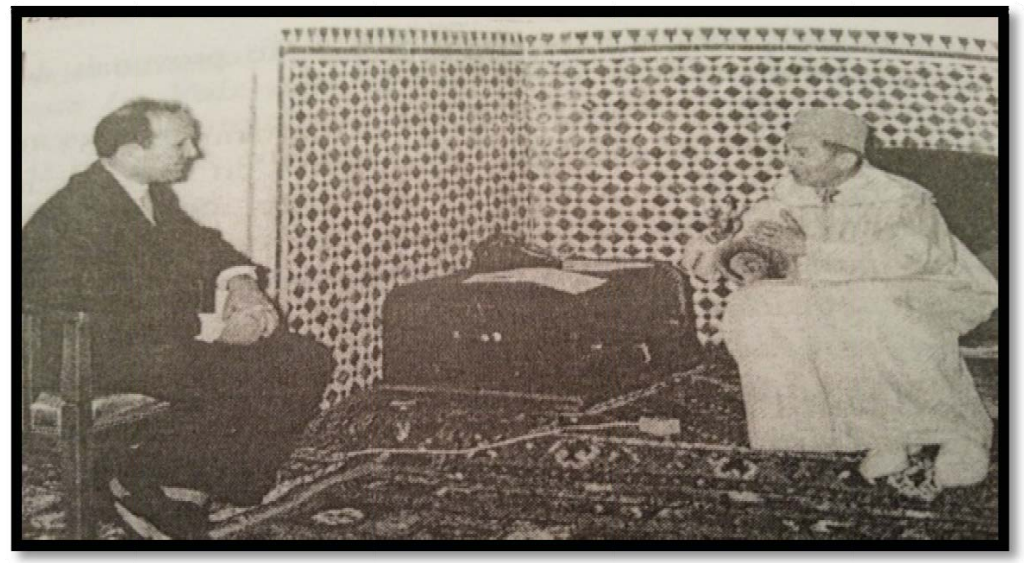

A general idea one could deduce is that during colonialism, there were no institutions or laws that effectively organized the press in Morocco, but after independence Morocco issued a press code on November 1958 which was published on Bulletin Officiel on November $27^{\text {th }}, 1958$. In other words, efforts were made by the state after independence in order to 'Morocconize' the press within a legal, modern, and liberal framework.

${ }^{5}$ Abdellatif Sbihi was a young nationalist, and he was the father of Pacha Sbihi of Salé. He graduated from L'Ecole des Langues Orientales de Paris. 
Figure 3: Press Code of 1958 published in Bulletin Officiel

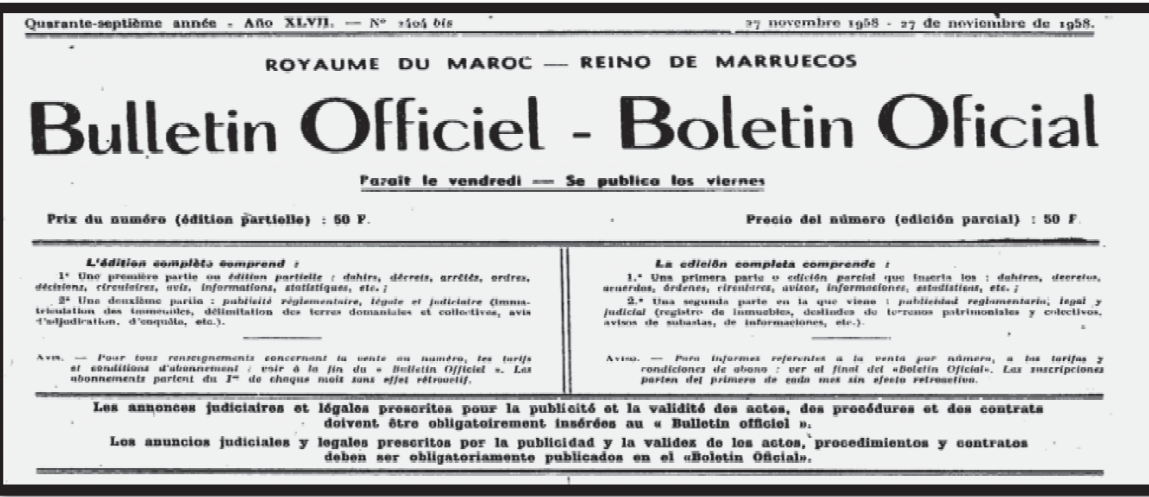

Since then, numerous newspapers saw light, and some of them, if not the majority, faced difficulties because of which they disappeared.

This is a brief overview of the Moroccan press before and during colonialism. This gradual development of the press during this period promised for a well-established culture of print journalism in Morocco as is the case today.

\section{The Press in Morocco Today}

Nowadays, newspapers are among the primary means whereby the information is conveyed in Morocco. It is undeniably the right of every individual to have access to the information. For instance, there are many associations in Morocco that have called for this right, and Transparency Maroc, a Moroccan association fighting against corruption, is illustrative of the case. Today, Morocco enjoys a solid infrastructure of print journalism and there is actually a considerable number of newspaper publications, including daily and weekly ones. These newspapers have allowed the country to know an important evolution of the press in terms of its content and its linguistic diversity. Newspapers edited in Arabic and in French are the most circulated, while there is no single newspaper edited in English! This is partly because the English readership in Morocco is still embryonic. In the second place, some British and American newspapers like the New York Times and the Independent appear from time to time in Moroccan big cities, especially Casablanca, but the problem is that they are very expansive and because of this Moroccans cannot afford them. The following statistics, taken from Rapport Annuel sur L'état de la Presse Ecrite et la Communication Audiovisuelle Publique 2006 (p.9), show the classification of Moroccan newspapers in terms of publication language.

Figure 4: Classification in terms of publication language

\begin{tabular}{|lcc|}
\hline Language & Titles & Percentage \\
\hline Arabic & 282 & $70,86 \%$ \\
\hline French & 107 & $26,88 \%$ \\
\hline Amazigh & 09 & $2,26 \%$ \\
\hline Total & 398 & $100 \%$ \\
\hline
\end{tabular}


Figure 5: Percentage in terms of publication language

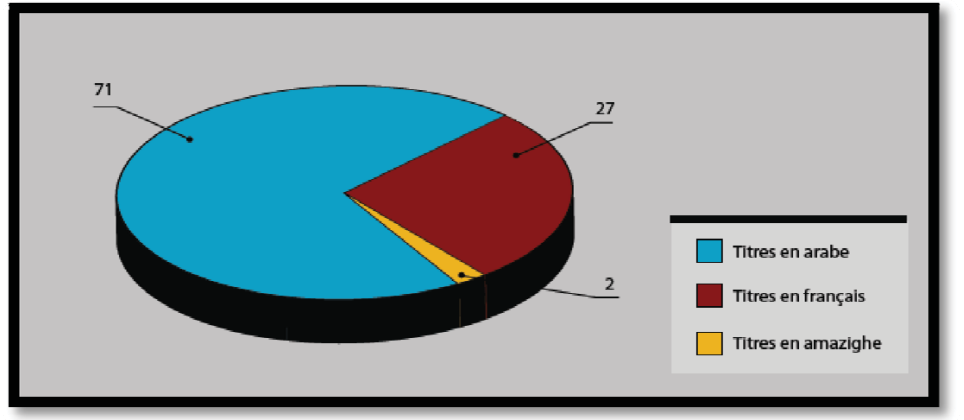

A general idea one could easily get from the above statistics is that the majority of newspapers in Morocco are published in Arabic, while also a significant number of others are published in French. Moha Ennaji (2005, p. 103) mentions that "there exist a multitude of Moroccan newspapers published in French" and that "the Moroccan press of French expression continued to exist and to develop even after the colonial press had vanished." Le Matin, l'Opinion, L'Economiste, and Libération are some of the well-known Moroccan newspapers of French expression. The annual report of 2004 mentions one single newspaper published in Spanish. The report of 2006 did not mention it because it had disappeared. The problem, as the statistics show, is with the newspapers published in Amazigh as the number is shockingly very low. Today, and with the new constitution, Amazigh has been institutionalized as an official language besides Arabic. Therefore, efforts should be made to achieve equilibrium between Arabic and Amazigh in the domain of journalism in particular, and in all media outlets in general.

Some newspapers in Morocco are partisan like Al- Alam and Al- Ittihad Al- Ichtiraki. According to the Moroccan Ministry of Communication's annual report of 2006, there are only 21 party-affiliated newspapers. (Ibid., p. 8) Almost each political party in the country has its own official newspaper through which it circulates its ideology and its political program. In general, such newspapers are officially affiliated to political parties, and they pay tribute to their political roots. It is worth noting that "partisan newspapers in Morocco are losing ground and therefore no longer prevailing." (Tayebi, 2012, p. 23) Aziz Bakouch, in one of his articles (www.ahewar.org), argues that Moroccans no more find trustworthiness in political parties in general, and in partisan papers in particular, claiming that it is the independent press that has immeasurably grown in readership in Morocco. This is very clear today in Morocco seeing that the majority of people shun politics and political parties, let alone partisan newspapers. What is very astonishingly paradoxical, Bakouch says (Ibid.), is that even the most prominent political figures in Morocco do not buy the newspapers of the political parties to which they belong.

Unlike the independent newspapers, the partisan ones in Morocco are financially dependent on the government's sponsorship, and this makes them state-regulated and with censorship hanging over them as the Sword of Damocles. This is actually very obvious because the partisan papers in Morocco never criticize certain sensitive issues. What is worse and shocking is that many ministers worked as directors of many party papers. Mohammed Ibahrine, in one of his interesting articles, refers to this phenomenon arguing that

\section{A significantly marked phenomenon in the Moroccan print press is that many ministers function as directors of newspapers. The Prime Minister directs Al Ittihad Al Ishtiraki, the Minister for Human Rights is responsible for Al Mitaq Al Watani and the former Minister of Education is the director of Bayan Al Youm. (Ibahrine, 2002, p. 637)}

For the sake of clarification, Ibahrine wrote his article in 2002 and he talks here about a particular period when ministers were the directors of the newspaper of the political party they belonged to. Very ironically does Ibahrine show the extent to which these papers "are destined to play a propagandist role and thus defend certain policies rather than practicing journalism, which informs the public." (Ibid.) These problems, especially the problem of censorship on the press have worries various international organizations like "Article 19", "Freedom Forum", and "Reporters sans Frontiers", "which expressed their concerns about the deterioration of the freedom of the press in Morocco." (Ibid.)

It would be a sort of truism to mention that the efforts that were made in the 1990s to politically liberalize Morocco have allowed the country to witness dramatic changes, and the emergence of the independent press is absolutely a very 
case in point. This was noticed above all with the socialists rise to power in the alternation government in 1997. Indeed, the government of 1997 contributed a good deal in the emergence of a free independent press in Morocco, the aim of which was the promotion and consolidation of democracy. (Ibid., p. 632) The appearance of Le Journal Hebdomadaire, a weekly independent magazine edited in French, in 1997 embodied a turning point in the realm of journalism in the country. Le Journal played a very crucial role as it paved the way for other newspapers and magazines, like Assahifa, AlMustaqil, Al Ayyam, Al-Massae, and Al Mich'al to see light. It is commonly known that "most of the independent newspapers emerged in the final years of the autocratic rule of King Hassan II at the end of the 1990s, when a new and relatively liberal press legislation was passed." (www.arabpressnetwork.org)

It would be important to refer to what normally determines the independent press. According to Houssin Mejdoubi (2010, p. 31), there are three basic things that characterize the independent press in general: ownership, content, and the sociology of reception. As long as ownership is concerned, we can claim that the first thing that characterizes this particular press is the fact that it is not owned by the state or by political parties. It is rather owned by new industries and by new people. (Ibid.) For example, Le Journal was owned by two journalists and one businessman, while Al-Ayyam is owned by the journalists who work within it. The second main new feature is in terms of the content. The content of the independent press is new so far that it sometimes deals with cultural taboos, and sometimes with the King, but without transcending the limits. Some broadsheets and magazines for example like Le Journal used to publish articles that tackle sensitive issues like the monarchy. As a result, this independent magazine was censored and many other broadsheets are now and then harassed by the state. The last point Mejdoubi suggests (Ibid., p. 32) is the sociology of reception and by this he means that that the independent press has been influential today as any other political institution. That is to say, it influences the political sphere, and it shapes the public opinion. Another interesting idea he adds is that there is always an alternative, meaning that new newspapers always show as alternatives for the current ones. These are the main specificities of the independent press which is crucial for any project towards democracy.

No one can deny the importance of the free independent press which is, as Azzedine Layachi notes in his State, Society, and Democracy in Morocco: The Limits of Associative Life (p. 68), "an absolute necessity for a democratic environment in which an effective civil society can exist." In this respect, Layachi adds (Ibid.) that "an independent press serves not only as a medium for civic associations to express their demands and objections, but also as a tool to publicly question and evaluate public policy and to hold office holders accountable." When looking at the literature about journalism, we come to know that that the concept that is used during the process to democracy is the "free press", but in Morocco the "independent press" is the most commonly used. Today in Morocco, the independent newspapers are the most circulated, representing the majority in the market. There are more than 400 independent newspapers in Morocco, and some of them are not published on a regular basis. All of these newspapers, including the partisan papers, are different in terms of the topics they cover and in terms of periodicity.

Morocco has already started the process of democratization, but the problem actually is that "studies in democratization routinely cover topics such as constitutional reforms and political parties, but, in some cases, give little space to mass media." (Ibahrine, 2002, p. 632) In fact, democratizing the press and mass media in general is the key to any shift to democracy. As Driss Maghraoui (2009, p. 144) argues, the case of Morocco is very complex in the sense that all the reforms that have taken place could be seen as contradictory because they do not refer to a democratic transition paradigm and, thus, preserve continuity and change at the same time. Since the 1990s, and with the arrival of King Mohamed VI in 1999, "more space is open for debates in the media." (Ibid., 143) It is actually the case of the independent press which, despite of the "self-censorship"6 phenomenon, "which includes avoiding attacks against or criticism of, the King, Islam, and Morocco's claim to the Western Sahara, has experienced in recent years a slight broadening of its range of action." (Layachi, 1998, p. 69) Accordingly, the democratization of the free press has allowed the latter to only question and criticize state actions, the political leaders' behavior (except the King and the royal family in general), as well as to analyze social, economic, and cultural issues. Maghraoui $(2009$, p. 145) argues in this regard that

Reforms have contributed to the enlargement of the space of political participation and provided better conditions for human rights, but they do not necessarily guarantee the rights of citizens to freely express their views. In Morocco, these rights stop when they reach [...] what is popularly known as the 'lignes rouges' or red lines. So the discourse

\footnotetext{
${ }^{6}$ Self-censorship is "self regulation by an individual author or publisher, or by the 'industry'. Media industries frequently remind their members that if they do not regulate themselves they will be regulated by the state. Self-censorship on the individual level includes the internal regulation of what one decides to express publically, often attributable to conformism." This definition is taken from Chandler's and Munday's Dictionary of Media and Communication (New York: Oxford Univ. Press, 2011), p. 44.
} 
about liberalization might be useful but the process is regularly faced by setbacks associated with the practice of fines against newspapers and occasional imprisonment of journalists.

Following Maghraoui's statement, reforms in Morocco have bettered the conditions of human rights without broadening enough the space of freedom of expression; that is, journalists do not have the right to shed light on sensitive issues, or on what is referred to as the red lines, such as the King, the royal family, the Moroccan's claim of the Sahara, to mention only a few. If these red lines are trespassed, newspapers get shut down and journalists fined. The Human Rights Watch's 2011 report (p. 87) concludes in this regard that

\begin{abstract}
Moroccan independent print and online media investigate and criticize government officials and policies but face prosecution and harassment when they cross certain lines. The law includes prison terms for "maliciously" spreading "false information" likely to disturb the public order or for speech that is defamatory, offensive to members of the royal family, or that undermines "Islam, the institution of the monarchy, or the territorial integrity," that is, Morocco's claim on Western Sahara.
\end{abstract}

Hence, claiming that the reforms that have been introduced since the beginning of the so-called "New Era" represent a radical departure from the past would be utterly incorrect. What is worse, according to lbahrine (2002, $p$. 639 ), is that the ministry of interior is also behind the restrictions of the freedom of the press, and that this impedes the "demakhzenization" of the Moroccan national information system from taking place, hence making "the emancipation of the national information system from political control [...] still far away." To put it simply, Morocco has embarked on the process of democratization, but the absence of freedom of expression, especially when it comes to the independent press, puts this process at stake and the so far introduced reforms under question.

The general idea of this discussion is to show the extent to which democratization and the press are immensely interrelated, and that, as Layachi notes (1998, p. 70), the "development of a truly free press is [...] one of the most important prerequisites of civil society and must be part of any process of genuine democratization."

In this short article, I have attempted to shed light on the Moroccan print journalism within its historical and contemporary contexts as well as on the the problems facing it, especially the problem of censorship, red lines, and selfcensorship. However, there are other challenges like the tabloidization of the Moroccan press about which I am intending to write an article and discuss in relation to the absence of ethics in professionalism. In my next article, I will look at the tabloidization of broadsheets in Morocco as it is ideological and also as a threat to the ethics of the independent press. In the second place, instead of raising the important issues of the public, the tabloidized broadsheet diverts the audience from the real serious cultural and political concerns of society through placing more emphasis on trivialities such as fashion, celebrities, gossip-based news, sensational news, advertisement, to mention but a few. In my MA. thesis, I argue that the shift from hard news to soft news in the Moroccan broadsheets is by far ideological, if not unethical. The next article will investigate and critically analyse at the phenomenon of tabloidization the Moroccan independent newspapers have recently witnessed.

\title{
References
}

Baida, L. (1996), Presse Marocaine D'Expression Française: Des Origines A 1956, Rabat, FLHS.

Cohen, P. (2007), La Presse Juive Editée au Maroc : 1870-1963, Rabat, Bouregrag.

El Ayadi, R. (2007), 'Evaluative Utterances in Colonial News-discourse: A case Study in The Times of Morocco', Diss., FLHS Abdelmalek Essaadi.

Ibahrine, M. (2002), 'Democratization and the Press: the Case of Morocco', in North-Sud Aktuell, No. 4, pp. 632-640.

Layachi, A. (1998), State, Society, and Democracy in Morocco: The Limits of Associative Life, Georgetown: Georgetown Univ. Press.

Maghraoui, D. (July 2009), 'Introduction: Interpreting Reform in Morocco', in Mediterranean Politics, 12, No. 2, pp. 143-149.

Meakin, B. (1899), The Moorish Empire, London, Swab Sonnenschein.

Mejdoubi, H. (2010), 'Assahafa Almoustaqilla Filmaghrib: Annachaa- Alkhitab Wa Mouiiqat Attatawor (2000-2004)', ['The Independent Press in Morocco: The Emergence- Discourse and Impedements'], Wijhat Nadar, Spring and Summer Issue, pp. 31-34.

Tayebi, H. (2012), Discourse Analysis of Moroccan Partisan Press: "Al Alam", "Al Ittihad Al Ichtiraki", and "Attajdid" as Case Studies, Germany: Lambert Academic Publishing.

\section{Websites}

Bakouch A., 'Ikhtifae Aljaraid Alhizbiya Mina Almaqahi Almaghribya: Assbab Wal Mouaawiqat,' ["The Disappearance of Partisan Newspapers in Moroccan cafés: Causes and Impedements"]," Al- Hiwar Al- Moutamaddin, June 30th, 2008. < 
http://www.ahewar.org/debat/show.art.asp?aid=139391>. Accessed on February 17th, 2013.

$<$ http://www.arabpressnetwork.org/newspaysv2.php?id=117>. Accessed on February 21st, 2013.

To see the Press Code of 1958, visit < http://www.ccisfes.org/images/telechargement/juridique/associations/dahir158376 droitdassociation.pdf>. Accessed on February 17th, 2013. 